JURNAL PANALUNGTIK

e-ISSN: 2621-928X — Vol. 4, No. 2, Desember 2021, pp $61-74$

DOI: https://doi.org/10.24164/pnk.v4i2.64

\title{
PEMANFAATAN LIMBAH KINA MASA LAMPAU DAN PENGEMBANGANNYA
}

\section{Utilization of Quinine Waste in The Past and Its Development}

\author{
Ria Intani T., Lasmiyati \\ Balai Arkeologi Jawa Barat \\ Jalan Raya Cinunuk Km. 17, Cileunyi, Bandung, Indonesia \\ E-mail: lasmiyatinizam@gmail.com
}

Naskah diterima: 12 Oktober 2021 - Revisi terakhir: 14 Desember 2021

Disetujui terbit: 14 Desember 2021 - Tersedia secara online: 17 Desember 2021

\begin{abstract}
As of today, quinine plants are still found in the Bukit Unggul Plantation, Bandung Regency, which is part of PT Perkebunan Nusantara VIII. Quinine is processed in the processing plant located in Bukit Unggul. In general, people have known quinine as an anti-malarial drug in which the ingredients were taken from the bark of the quinine tree trunk, afterward it becomes waste. In the past, quinine waste was used as firewood and building material for offices, factories, and homes for plantation worker. In its development, there were those who use quinine waste to make furniture to meet their own needs. The results showed that the previous idea of using quinine waste inspired people in the future to utilize and develop quinine waste into furniture, in a sense of worth-selling furniture. The purpose of this study is to demonstrate the utilization of quinine waste in the past and its development. This is descriptive research with a qualitative approach. The data collection was carried out using interview, observation, and documentation studies. The conclusion of the study is that the discourse about quinine became widespread, not only limited to medicine, but also building materials and crafts.
\end{abstract}

Keywords: utilization, development, quinine waste

\begin{abstract}
Abstrak
Tanaman kina saat ini di antaranya masih terdapat di Perkebunan Bukit Unggul Kabupaten Bandung yang merupakan bagian dari PT Perkebunan Nusantara VIII. Di Bukit Unggul, kina diolah di pabrik pengolahan yang ada di sana. Umumnya orang mengenal kina sebagai obat anti malaria dengan bahannya diambil dari kulit batang pohon kina, setelahnya, batang kina menjadi limbah. Dulu, limbah kina dimanfaatkan sebagai kayu bakar dan material bangunan pabrik, kantor, dan rumah karyawan perkebunan. Dalam perkembangannya, ada yang memanfaatkan limbah kina untuk dibuat mebel untuk memenuhi kebutuhan sendiri. Hasil penelitian menunjukkan bahwa gagasan lama atas pemanfaatan limbah kina menginspirasi orang di kemudian hari untuk memanfaatkan dan mengembangkan limbah kina untuk dibuat mebel, dalam arti mebel yang layak jual. Tujuan dari penelitian ini untuk menunjukkan pemanfaatan limbah kina pada masa lampau dan pengembangannya. Penelitian ini bersifat deskriptif dengan pendekatannya kualitatif. Adapun penggalian datanya dilakukan dengan menggunakan teknik wawancara, observasi, serta studi dokumentasi. Simpulan dari penelitian adalah bahwa wacana tentang kina menjadi luas, tidak sebatas tentang obat, akan tetapi juga material bangunan dan kerajinan.
\end{abstract}


Kata kunci: pemanfaatan, pengembangan, limbah kina.

\section{PENDAHULUAN}

Bukit Unggul merupakan perkebunan kina yang semula bernama Bukit Tunggul. Bukit Tunggul berasal dari kata bukit dan tunggul. Kata tunggul berasal dari kosakata bahasa Sunda yang berarti pangkal pohon. Pada saat batang-batang kina ditebang untuk diambil kulitnya, tinggal tunggul atau pangkal pohon (kina) yang masih tertanam di tanah. Dengan banyaknya tunggul pohon kina maka perbukitannya lalu diberi nama Bukit Tunggul ${ }^{1}$. Seiring dengan berdirinya pabrik kina di Bukit Tunggul, nama Tunggul diganti menjadi Unggul sehingga menjadi Bukit Unggul. Nama unggul dimaksudkan agar pohonpohon kina yang tumbuh di Bukit Tunggul dapat menjadi hasil perkebunan yang unggul ${ }^{2}$.

Perkebunan Bukit Tunggul di 2018 (Juli) merupakan gabungan dari dua kebun, yaitu Bukit Unggul dan Sukawana. Keduanya bersatu dalam satu manajemen dengan nama yang digabungkan dan masing-masing menjadi kebun afdeling. Dengan demikian, perkebunan Bukit Unggul-Sukawana memiliki dua afdeling kebun, yaitu (1) Afdeling Bukit Unggul dan (2) Afdeling Sukawana, dengan komoditas kina dan teh (Nuralia et al. 2018).

Budidaya kina di Pulau Jawa dipelopori oleh Franz Wilhelm Junghuhn. Tahun 1856, di Pulau Jawa baru ada 167 pohon. Enam setengah tahun berikutnya berhasil dikembangkan menjadi 1.359.877 pohon. Setelah Junghuhn meninggal dunia pada 24 April 1864, pembudidayaan tanaman kina secara besar-besaran dilakukan di utara distrik Ujungberung Kulon dan Ujungberung Wetan, dan Pemerintah Belanda pun berhasil mendatangkan 500 gram benih kina dari Bolivia (Widjaya 2009).

Tanaman kina menghasilkan lebih dari 30 jenis alkaloid dan yang terpenting adalah golongan kuinolin yaitu kinin, konidin, sinkonin, dan sinkonidin. Senyawa kinin dan konidin merupakan bahan baku obat penyakit malaria dan penyakit jantung, juga sebagai bahan penimbul rasa pahit dan pencerah dalam minuman ringan (Sumaryono et al. 2009). Kondisi kuantitas tanaman kina yang terus menurun dimungkinkan karena kina tidak lagi merupakan komoditas utama bagi perkebunan, melainkan hanya sebagai komoditas pendukung. Hal ini di antaranya disebabkan biaya investasi cukup mahal. Investasi budidaya kina relatif lambat mengingat masa panen kina yang baru bisa dilakukan minimal setelah tujuh tahun. Ditambah lagi tanaman kina mudah mati setelah proses pemangkasan batang kinanya, dan saat ini banyak alternatif bahan untuk obat anti malaria selain kina. Hal-hal tersebut rupanya yang menjadikan upaya peremajaan tanaman kina menjadi harus dipikirkan ulang.

Pohon kina diambil kulitnya untuk bahan obat. Proses pengambilan kulit dilakukan di kebun dengan cara menebang batang pohon, selanjutnya batang tersebut dipukul-pukul atau istilah setempat adalah dipekprek untuk diambil kulitnya. Setelah itu, batang-batang kina yang cukup besar diambil oleh pihak perkebunan untuk dijadikan

\footnotetext{
${ }^{1}$ Wawancara dengan Ubes, 75 tahun, Pensiunan Perkebunan Bukit Unggul, 4 Oktober 2021.

${ }^{2}$ Wawancara dengan Andri, 41 tahun, Pemeriksa Intern Kebun (PIK), 4 Oktober 2021.
} 
bahan bakar di mesin pemanggangan/penggarangan di pabrik pengolahan kina. Selain itu, batang kina oleh pihak perkebunan juga digunakan untuk material bangunan pabrik, kantor, dan rumah karyawan perkebunan. Selebihnya, batang-batang kina yang lain dibiarkan terserak begitu saja. Oleh karena itu, warga mengambil limbah kina tersebut untuk dimanfaatkan sebagai bahan bakar untuk keperluan memasak. Bangunan-bangunan tersebut sebagai tinggalan budaya benda menunjukkan adanya pemanfaatan limbah kina di masa lampau. Seperti apakah pemanfaatan limbah kina pada masa lampau dan bagaimana pengembangannya pada masa sekarang, menjadi permasalahan dalam penelitian ini. Tujuan dari penelitian ini untuk menunjukkan pemanfaatan limbah kina pada masa lampau dan pengembangannya.

Penelitian ini bersifat deskriptif dengan pendekatan kualitatif. Adapun penggalian datanya dilakukan dengan menggunakan teknik wawancara terbuka, observasi lapangan, serta studi dokumentasi. Pendekatan kualitatif atau sering disebut fenomenologis, yaitu melihat segala sesuatu adalah sesuatu itu sendiri, tidak ada persepsi untuk mengaburkan makna gejala (Saebani 2012).

Penelitian terkait dengan perkebunan kina ataupun Perkebunan Bukit Unggul sudah dilakukan oleh para peneliti, namun belum ada yang menyinggung kebermanfaatan limbah kina. Dengan demikian, penelitian ini mengisi celah yang masih kosong dan dapat melengkapi penelitian terdahulu.

Penelitian berjudul Penetapan Potensi Unggulan Kecamatan di Kabupaten Bandung menguraikan potensi sektor unggulan di Kabupaten Bandung meliputi pertanian, perkebunan, peternakan, perikanan, industri dan pariwisata. Pada penelitian tersebut diamati empat kecamatan. Salah satunya adalah Cilengkrang yang memiliki produk unggulan di bidang perkebunan (Rukmana et al. 2020).

Penelitian berikutnya berjudul Analisis Nilai Ekonomis Wisata Kebun Kina Bukit Unggul Kabupaten Bandung (Wanti, Syaukat, dan Juanda 2014). Penelitian ini menyoroti tentang Kebun Kina di Bukit Unggul yang dijadikan sebagai objek wisata. Kebun Bukit Unggul merupakan salah satu unit bisnis PT Perkebunan Nusantara VIII dengan core business adalah komoditas kina. Kebun Bukit Unggul memiliki program investasi yaitu pengembangan wisata kebun dan 2009 mengembangkan objek wisata yang diberi nama Agrowisata Kebun Kina Bukit Unggul.

Penelitian berikutnya berjudul Strategi Pengembangan Daya Tarik Wisata Kebun Kina Bukit Unggul di Kabupaten Bandung (Fauzi 2017). Dalam penelitiannya Rizal Ahmad Fauzi mengatakan bahwa di Bukit Unggul terdapat beberapa objek wisata alam maupun buatan di antaranya adalah wisata edukasi pengolahan kina.

Penelitian lainnya oleh Lia Nuralia. Lia melakukan penelitian terkait dengan bangunan dan hasil produksi dari dua perkebunan dengan judul penelitiannya "Bangunan dan Produksi Perkebunan Panglejar dan Bukit Unggul-Sukawana Kabupaten Bandung Barat Provinsi Jawa Barat". Selanjutnya Lia Nuralia bersama Iim Imadudin (2021) menulis tentang perkebunan kina di Cinyiruan. Penelitian ini fokus pada masalah nilai budaya pada lanskap industri perkebunannya. 


\section{HASIL DAN PEMBAHASAN}

\section{Sejarah Perkebunan di Jawa Barat}

Sebelum kedatangan bangsa Eropa ke Kepulauan Nusantara, masyarakat telah mengembangkan dua tipe kegiatan pertanian, yaitu pertanian yang menggarap tanaman subsisten dan tanaman perdagangan. Dari ragam kegiatan pertanian terdapat empat sistem pertanian: 1) sistem perladangan yaitu jenis kegiatan pertanian yang dilakukan secara berpindah-pindah dengan penanaman berbagai tanaman berumur pendek, terutama tanaman pangan; 2) sistem pesawahan; 3) sistem kebun, yaitu kegiatan pertanian yang menggarap tanaman berusia panjang atau tanaman penghasil panenan yang ditanam pada lahan tetap; dan 4) sistem tegalan, yaitu tipe kegiatan penanaman tanaman pangan pada daerah lahan kering (Kartodirdjo dan Surjo 1991). Jenis tanaman yang ditanam di kebun adalah jenis tanaman yang memiliki nilai jual.

Pada 1854 dan 1856, pemerintah kolonial mengeluarkan peraturan dengan mengizinkan pihak swasta untuk mengelola perkebunan, dengan ketentuan penyewaan tanah yang kosong dan bukan milik penduduk untuk waktu 20 tahun. Sistem penyewaan tanah milik penduduk dan penyewaan tanah harus diolah atau dikerjakan oleh penduduk itu sendiri, petani harus mengerjakan tanahnya sendiri, pekerja lain tidak diperkenankan (Proyek Penerbitan Buku Sejarah Jawa Barat 1980). Ketentuan peraturan ini tidak dapat berjalan dengan baik, karena selain ada batasan waktu selama 20 tahun, juga ada penduduk yang tanahnya disewa tapi belum tentu mau bekerja di tanah miliknya. Hal itu menyebabkan walaupun tanah-tanah di Jawa Barat banyak yang kosong akan tetapi pihak swasta enggan mematuhi peraturan tersebut. Menggunakan politik mencari keuntungan, pemerintah kolonial mencari tanaman yang laku di pasar internasional. Antara 1870 dan 1900, di Indonesia disebut dengan zaman liberalisme, yaitu pihak swasta yang memiliki modal diberikan peluang untuk menanamkan modalnya. Penanaman modal dapat dilakukan dalam berbagai usaha dan kegiatan di Nusantara, khususnya di bidang perkebunan baik di Pulau Jawa maupun di luar Jawa. Selama masa itu, pihak swasta dari Belanda dan negara-negara Eropa yang memiliki modal, mendirikan berbagai perkebunan, seperti perkebunan teh, kopi, gula, dan kina (Kartodirdjo 1975).

Kebun-kebun kina di Indonesia kebanyakan terdapat di Jawa Barat, seperti di Bandung, Pangalengan, Cibeureum, Cianjur, dan Garut. Hal ini disebabkan pada waktu itu ada anjuran dari Pemerintah Belanda kepada rakyat agar menanam dan menyebarluaskan tanaman kina. Benih-benih diberikan secara cuma-cuma (Proyek Penerbitan Buku Sejarah Jawa Barat 1980). Di Bandung terdapat Perkebunan Kina Bukit Unggul, lokasi perkebunan termasuk di wilayah Kecamatan Cilengkrang, Kabupaten Bandung (Gambar 1). Topografi kawasan berupa area pebukitan pada ketinggian antara 1500 - 1680 m dpl. Bukit Unggul dapat dicapai melalui dua jalur, yaitu Lembang dan Ujungberung (Officieele Vereeniging voor Toeristenverkeer in Nederlandsch-Indie 1939). Jalur dari Lembang ke arah timur dengan jarak 15-18 km melalui Cikidang, Maribaya, Leuweungdatar, Cibodas, Bukit Unggul. Sedangkan jalur melalui Ujungberung ke arah utara berjarak $11 \mathrm{~km}$ melalui Palintang, Gunung Kasur, Bukit Unggul (Gambar 2 dan Gambar 3). Pegunungan Bukit Unggul merupakan lahan miring 
sehingga cocok untuk tanaman kina. Apalagi lereng bukit yang berkontur miring sekitar 30-45 ini ditata dengan undakan-undakan tanah atau terasering sehingga akan memudahkan dalam menanam kina (Nuralia dan Imadudin 2021).

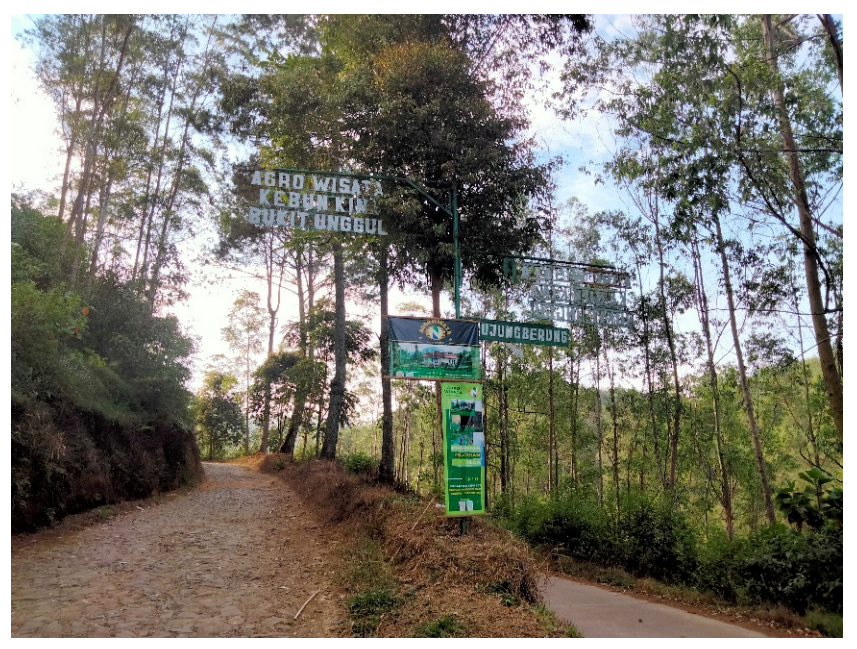

Gambar 1. Jalan menuju Perkebunan Bukit Unggul (Sumber: Dokumen BPNB Jawa Barat, 2021)

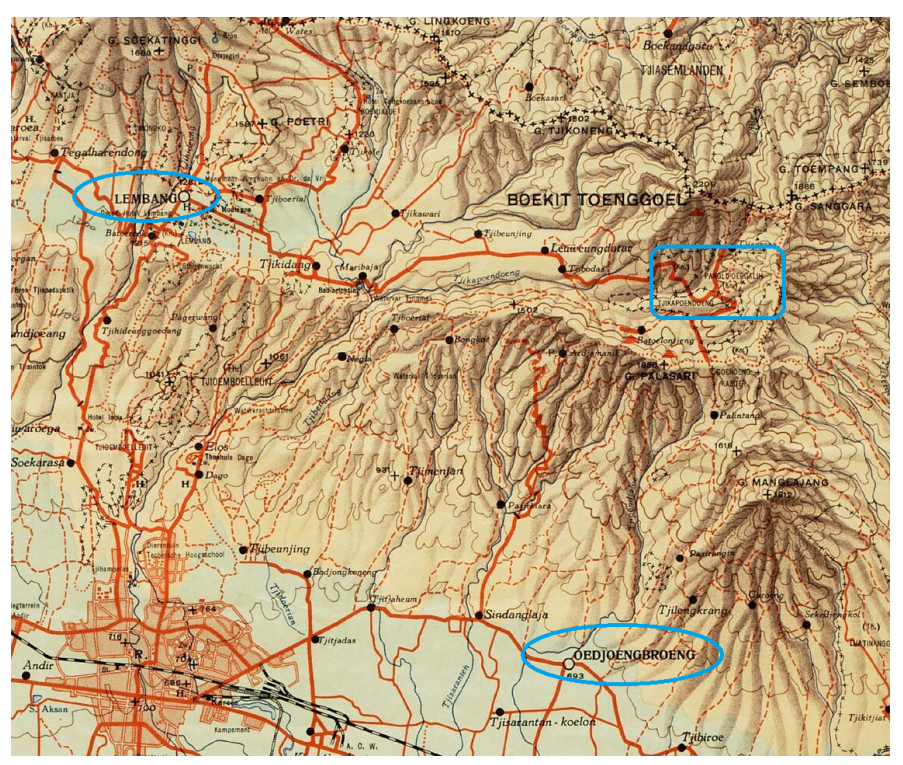

Gambar 2. Peta topografi lokasi Perkebunan Bukit Unggul (Sumber: Officieele Vereeniging voor Toeristenverkeer in Nederlandsch-Indie 1939) 


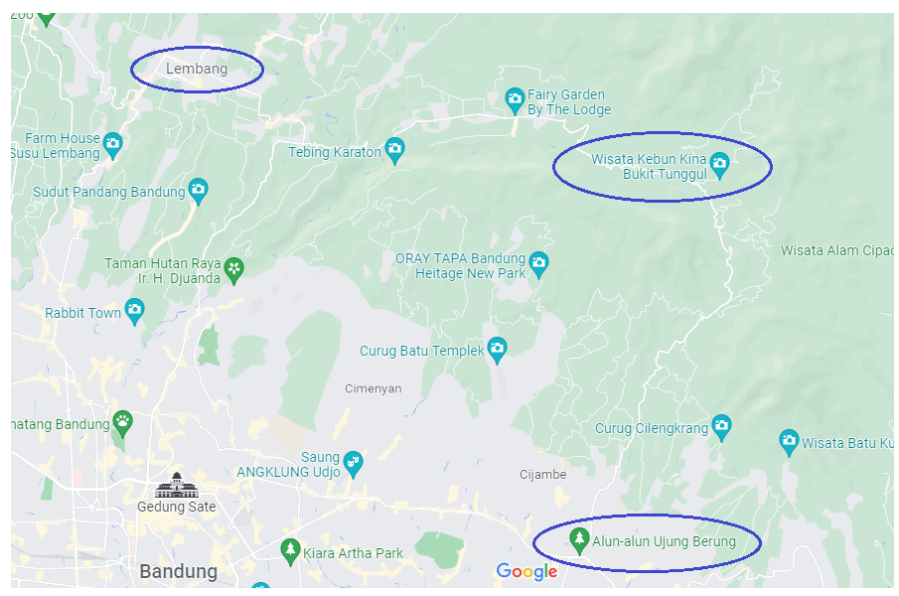

Gambar 3. Peta lokasi Perkebunan Bukit Unggul (Sumber: Google Maps, 2021).

Sebelum 1985 pohon kina di Bukit Unggul dibiarkan tumbuh selama 13 sampai dengan 15 tahun. Tahun-tahun sesudahnya, pohon yang berusia 7 hingga 8 tahun sudah ditebang. Padahal, pohon tersebut semakin tua akan semakin besar batangnya. Hal ini akan berpengaruh pada kulit yang dihasilkan menjadi lebih banyak ${ }^{3}$.

\section{Tinggalan Masa Lampau Berbahan Limbah Kina dan Pengembangannya}

Kebudayaan mempunyai tiga wujud, ialah: (1) Wujud kebudayaan sebagai suatu kompleks dari ide-ide, gagasan, nilai-nilai, norma-norma, peraturan dan sebagainya; (2) Wujud kebudayaan sebagai suatu kompleks aktivitas kelakuan berpola dari manusia dalam masyarakat; (3) Wujud kebudayaan sebagai benda-benda hasil karya manusia (Koentjaraningrat 1990). Di lingkungan masyarakat Perkebunan Bukit Unggul terdapat berbagai ide yang terlihat pada benda-benda sebagai tinggalan budaya. Salah satu ide yang dibahas dalam kajian ini adalah pemanfaatan dan pengembangan limbah kina. Dari ide tersebut kemudian muncul benda-benda sebagai buah pikiran dan tindakan. Bendabenda yang dimaksud berwujud bangunan dan berkembang menjadi material kerajinan mebel.

Bangunan dalam kawasan Perkebunan Kina Bukit Unggul, sebagaimana produk perkebunannya, berbahan material limbah kina berupa batang. Bangunan tersebut berupa pabrik, kantor, dan rumah karyawan/pegawai. Penggunaan limbah kina sebagai material bangunan dilatarbelakangi adanya limbah kina yang sudah tidak dimanfaatkan selain sebagai kayu bakar. Meskipun demikian, perlakuan terhadap limbah kina tersebut lebih dahulu didasari pengetahuan terkait dengan pohon (batang) kina, kekuatan dan kelemahannya. Dengan demikian banyaknya limbah kina yang tidak termanfaatkan bukan berarti digunakan begitu saja. Batang kina diketahui memiliki kekuatan hingga puluhan tahun sepanjang tidak langsung terkena sinar matahari. Tidak ada perlakuan khusus untuk limbah kina yang akan digunakan selain dijemur beberapa hari untuk menurunkan kadar air.

\footnotetext{
${ }^{3}$ Wawancara dengan Ubes, 75 tahun, Pensiunan Perkebunan Bukit Unggul, 4 Oktober 2021.
} 
Pabrik Kina Bukit Unggul didirikan 1927 dengan fungsi untuk mengolah kulit kina kering ${ }^{4}$. Pabrik Kina Bukit Unggul adalah satu-satunya pabrik kina yang masih produksi sampai sekarang. Ruang dalam pabrik dibagi menjadi empat, yaitu ruang penjemuran, pemanggangan/penggarangan, penggilingan, dan ruang pengepakan (Gambar 4). Eksterior dinding bangunan pabrik menggunakan batang kina.

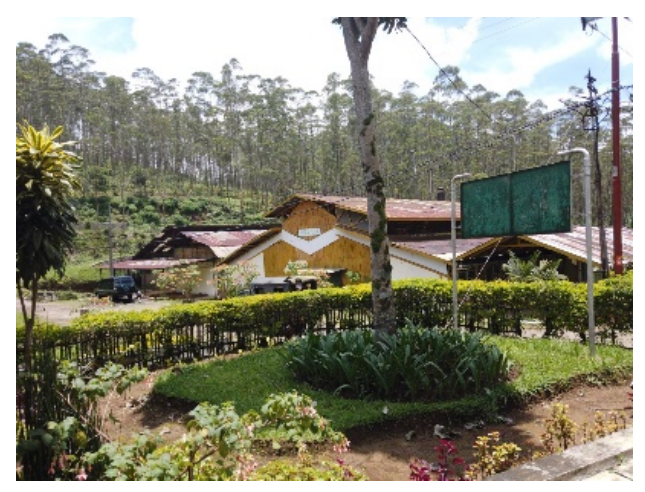

a

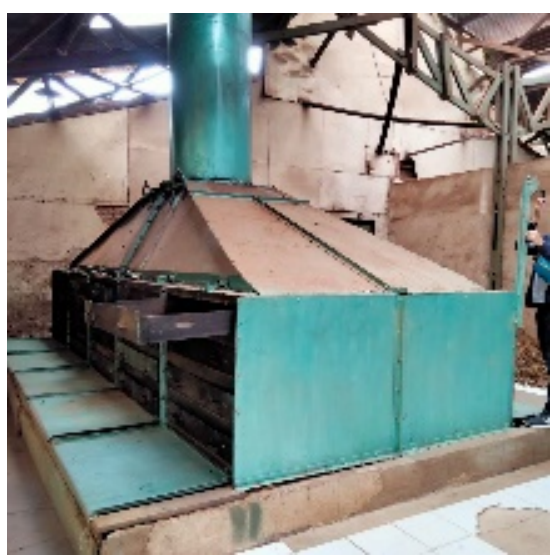

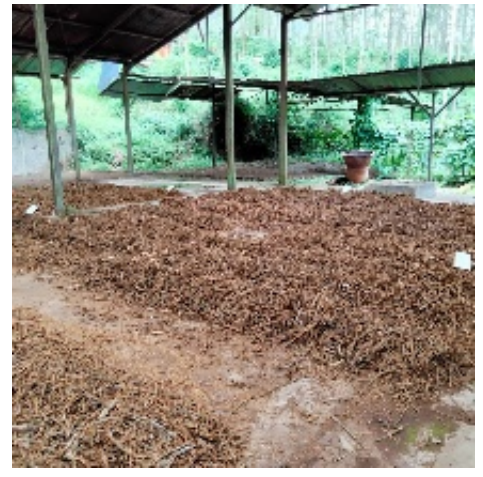

b

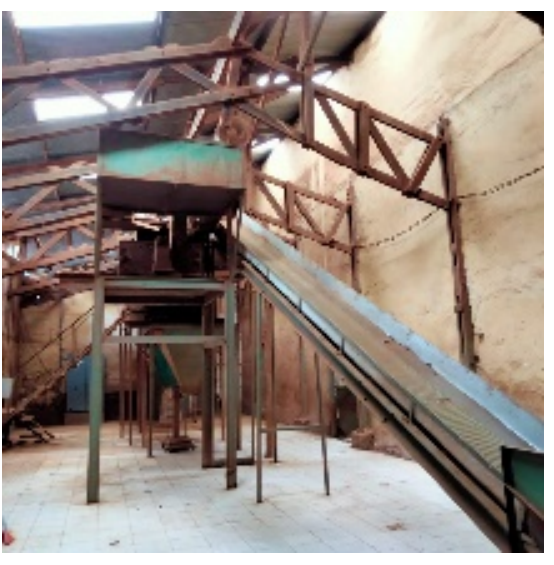

d

Gambar 4. Pabrik Kina Bukit Unggul (a), Ruang Penjemuran (b), Pemanggangan/Penggarangan (c), Penggilingan (d) (Sumber: Dokumen BPNB Jabar, 2021)

Bersamaan dengan dibangunnya pabrik, diperkirakan dibangun pula kantor induk administrasi dan rumah karyawan/pegawai perkebunan. Pembangunan berbagai fasilitas perkebunan itu juga memanfaatkan limbah kina. Pada bangunan kantor induk administrasi, limbah kina digunakan sebagai material eksterior dinding (Gambar 5). Selain itu pada bagian interior misalnya penyekat antarruang juga ada yang dibuat dengan memanfaatkan batang kina.

\footnotetext{
${ }^{4}$ Wawancara dengan Ima, 38 tahun, Bagian Administrasi Perkebunan Bukit Unggul-Sukawana, 25 November 2021.
} 


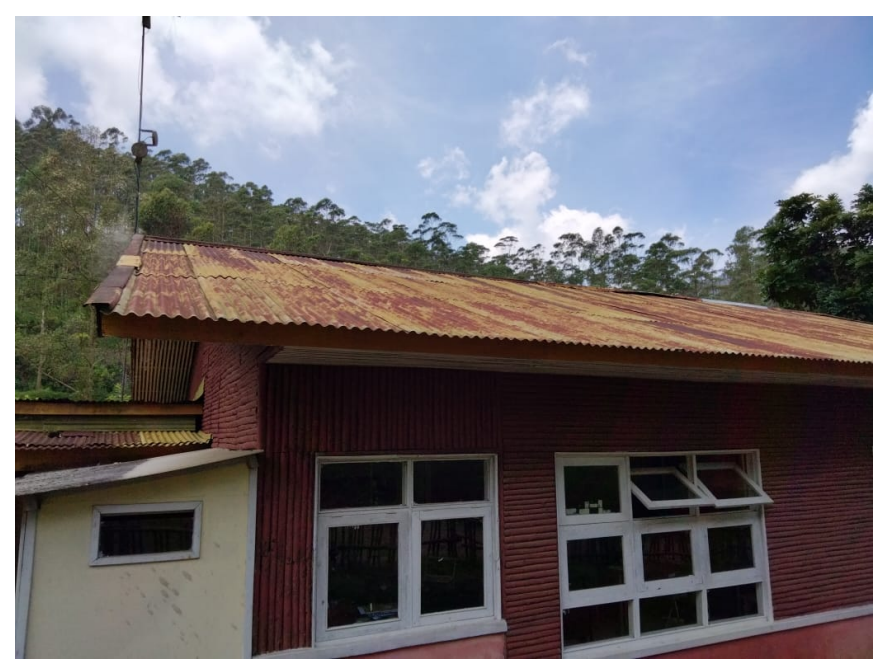

Gambar 5. Bangunan Kantor Induk Administrasi Perkebunan Bukit Unggul-Sukawana (Sumber: Dokumen BPNB Jabar, 2021)

Rumah karyawan perkebunan dibuat oleh pihak perkebunan. Pemanfaatan limbah kina untuk bangunan rumah karyawan di antaranya digunakan sebagai penyangga rumah panggung bertipe kopel (Gambar 6), kerangka atap, dinding luar bangunan, pagar, dan tangga (Gambar 7).

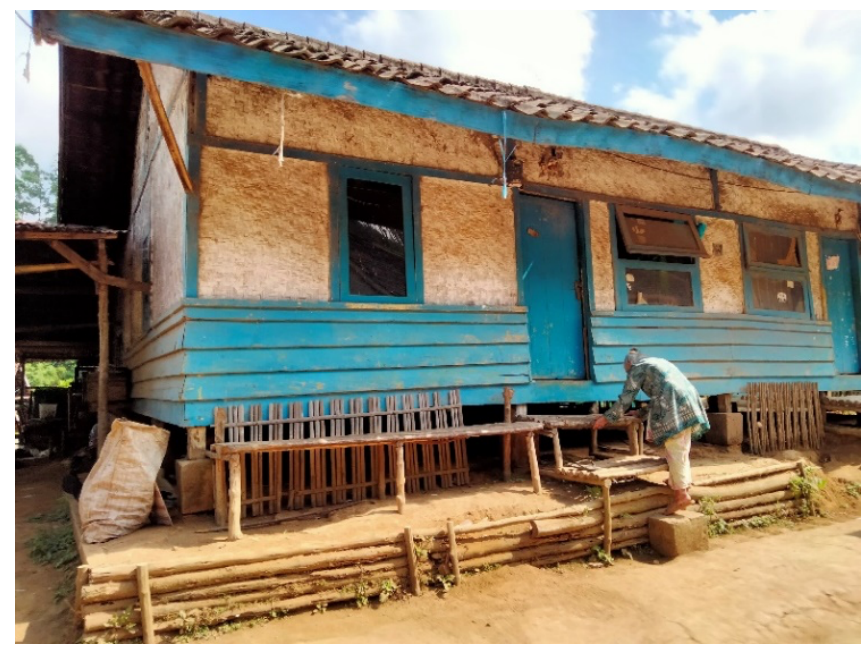

Gambar 6. Rumah karyawan/pegawai perkebunan Bukit Unggul berbentuk panggung tipe kopel (Sumber: Dokumen BPNB Jawa Barat, 2021) 

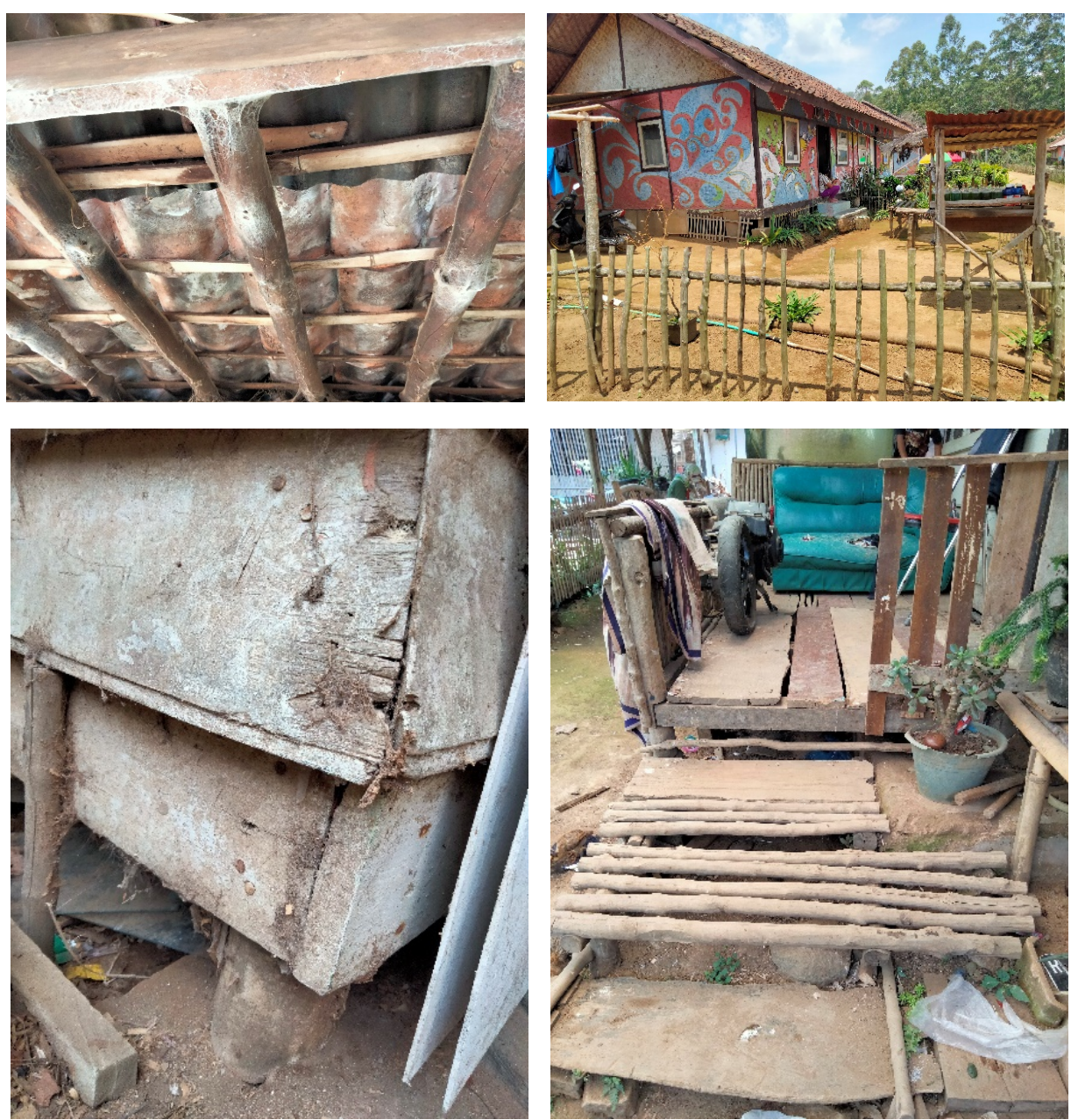

Gambar 7. Pemanfaatan limbah kina sebagai material rumah karyawan perkebunan (Sumber: Dokumen Ria Intani T., 2021)

Ide pemanfaatan limbah kina muncul pada seorang warga. Limbah kina dimanfaatkan untuk dibuat mebel berupa bangku untuk keperluan sendiri (Gambar 8). Bentuk dan pembuatannya relatif masih sederhana, yang dipentingkan adalah fungsi. Sama halnya dengan pemanfaatan untuk material bangunan, bahan yang digunakan untuk mebel berupa batang kina juga terlebih dulu dijemur beberapa hari. Cara menghaluskan batang kina masih menggunakan pecahan kaca. Teknik pemasaran masih sangat sederhana. Jika ada orang yang memerlukan bangku maka mebel buatannya dibarter dengan barang yang diperlukan, misalnya barang elektronik ${ }^{5}$.

\footnotetext{
${ }^{5}$ Wawancara dengan Aep, 42 tahun, Karyawan Perkebunan Bukit Unggul dan Pengrajin Limbah Kina, 4 Oktober 2021.
} 


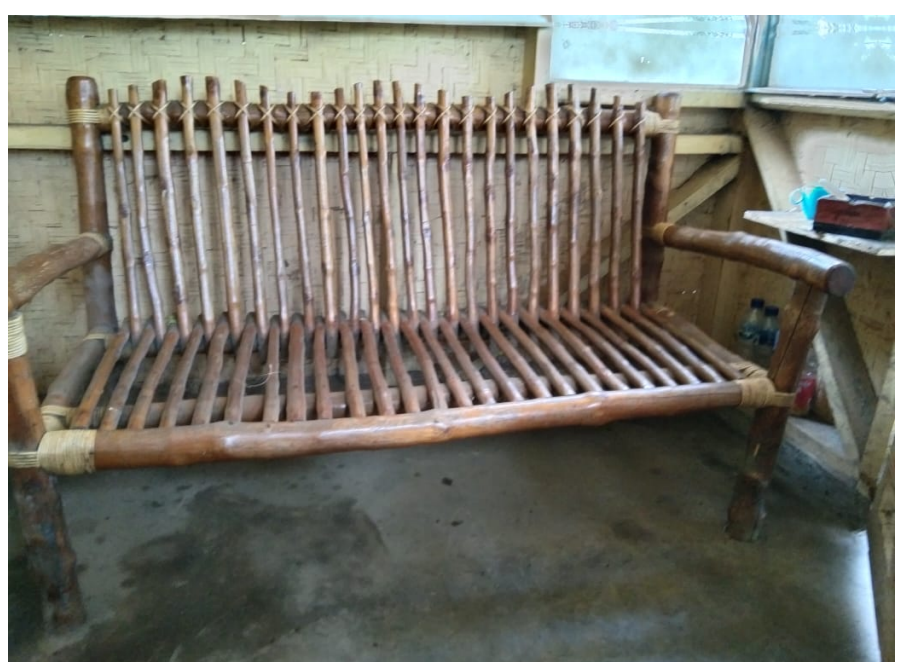

Gambar 8. Bangku berbahan limbah kina (Sumber: Dokumen Aep, $\mathrm{tt}$ )

Dalam perkembangannya, mebel tidak hanya dibuat untuk memenuhi kebutuhan sendiri, melainkan sebagai produk yang layak jual. Gagasan atau ide pembuatan mebel yang berakar dari pemanfaatan limbah kina di masa lampau berkembang di masa kini. Kampung Bukit Unggul, Desa Cipanjalu dihuni 183 kepala keluarga (KK) dengan penduduknya lebih kurang 30 orang bekerja di perkebunan, sisanya sebagai buruh tani sayuran dan palawija ${ }^{6}$. Sebagai mata pencaharian tambahan terdapat penduduk yang menjadi perajin mebel berbahan limbah kina. Dahulu ada beberapa orang perajin sekarang tinggal satu. Hal ini disebabkan keterbatasan bahan baku batang kina. Batang kina yang semula melimpah, seiring dengan menurunnya produksi, sekarang susah didapatkan. Kualitas batang kina pun mengalami penurunan. Dahulu pohon kina ditebang pada kondisi umur sudah tua sehingga batangnya besar. Sekarang pohon kina pada umur yang belum begitu tua sudah ditebang sehingga diameter dan kualitas batang tidak maksimal. Selain faktor bahan, secara ekonomik faktor permodalan dan promosi juga kurang memadai. Walaupun begitu, meningkatnya teknologi dalam memproduksi dan berkembangnya gagasan untuk menciptakan bentuk produk menjadikan kerajinan mebel berbahan batang kina dapat terus bertahan. Produk mebel yang semula hanya untuk mencukupi keperluan sendiri berkembang menjadi produk bernilai ekonomis.

Perajin mebel di Kampung Bukit Unggul memproduksi barang dilakukan selepas melaksanakan pekerjaan utama sebagai karyawan di Kantor Perkebunan Bukit UnggulSukawana. Usaha sambilan mebel ini dimulai 2019. Kemampuan membuat mebel didasari pengalaman saat membantu membuat mebel di sekitar 1985. Kualitas mebel berbahan kina lebih kuat jika dibandingkan dengan mebel berbahan kayu jati yang sekarang banyak beredar di pasaran. Hal ini karena kebanyakan bahan yang digunakan berasal dari kayu jati yang masih berusia muda. Namun demikian, karena bahan kayu jati lebih dikenal di masyarakat maka memiliki pasar lebih bagus sehingga harga jualnya pun menjadi lebih tinggi.

\footnotetext{
${ }^{6}$ Wawancara dengan Ihsan, 39 tahun, Karyawan Perkebunan Bukit Unggul dan Ketua RT 04, 4 Oktober 2021.
} 
Dahulu, pengadaan batang pohon kina dibawa sendiri dari kebun saat perajin usai bertugas mengawasi keamanan kebun. Saat ini batang kina dipesan dari seseorang yang biasa mengambil batang kina untuk kayu bakar. Perajin tersebut menyebutnya sebagai pengumpul kina yang kemudian menjadi langganannya. Pemesanan batang kina pada pengumpul kina maksimal sebulan sekali. Jumlah batang kina yang diterima berkisar dua puluh lima batang. Jumlah tersebut berasal dari beberapa pohon. Selain itu, kadangkala batang kina juga bisa dibeli di pabrik manakala ada batang kina yang tidak terpakai sebagai bahan bakar.

Penggunaan bahan batang kina disesuaikan dengan ukuran dari jenis mebel yang akan dibuat. Pohon kina yang belum berumur tujuh tahun sudah dipanen atau ditebang, dapat dipastikan batangnya sangat kecil. Berbeda dengan pohon yang sudah berumur tua, batangnya pun akan lebih besar dan kualitasnya lebih bagus. Batang berukuran kecil dipakai untuk membuat mebel dan pernak-pernik misalnya untuk figura. Batang yang berukuran besar untuk jenis mebel yang lebih besar.

Selain batang kina, selanjutnya untuk mewujud sebagai mebel digunakan bahan pendukung berupa paku, lem kayu, dan pernis/pelitur. Mebel dibuat dengan proses yang lebih kompleks dan dengan alat lebih memadai seperti tatah serta alaat penyerut, bor, dan mesin profil bersifat elektrik yang tidak lagi berupa alat manual. Pada tahap penyelesaian dipakai alat poles elektrik dan hampelas sebagai pengganti pecahan kaca yang digunakan pada masa lampau.

Teknik dan model mebel dibuat menjadi lebih kekinian. Bentuk mebel yang awalnya hanya berupa bangku sederhana dengan melalui proses dan warna apa adanya, saat ini dibuat dengan model dan melalui proses yang lebih kompleks. Mebel dikembangkan dalam beragam fungsi, bukan hanya bangku, melainkan juga meja, kursi, gantungan baju dan topi, pigura, serta rak sepatu dengan model kekinian (Gambar 9).

Perkembangan pemanfaatan limbah kina teruntama untuk barang-barang mebel terjadi karena adanya dinamika kebudayaan. Kebudayaan bersifat dinamis dan karenanya dapat berubah seiring perkembangan zaman. Parsudi Suparlan (1980/1981) sebagaimana dikutip Rosyadi (2011) mengemukakan bahwa perubahan kebudayaan adalah perubahan yang terjadi dalam sistem ide yang dimiliki bersama oleh para warga masyarakat yang bersangkutan, yang antara lain mencakup aturan-aturan, norma-norma yang digunakan sebagai pegangan dalam kehidupan warga masyarakat, nilai-nilai, teknologi, selera dan rasa keindahan atau kesenian, serta bahasa. T.O. Ihromi (1980) mengemukakan, secara umum penyebab perubahan kebudayaan dan masyarakat bisa terjadi melalui dua sumber, dari dalam masyarakat dan kebudayaan itu sendiri (faktor internal) serta perubahan yang datangnya dari luar masyarakat dan kebudayaan yang bersangkutan (faktor eksternal). 

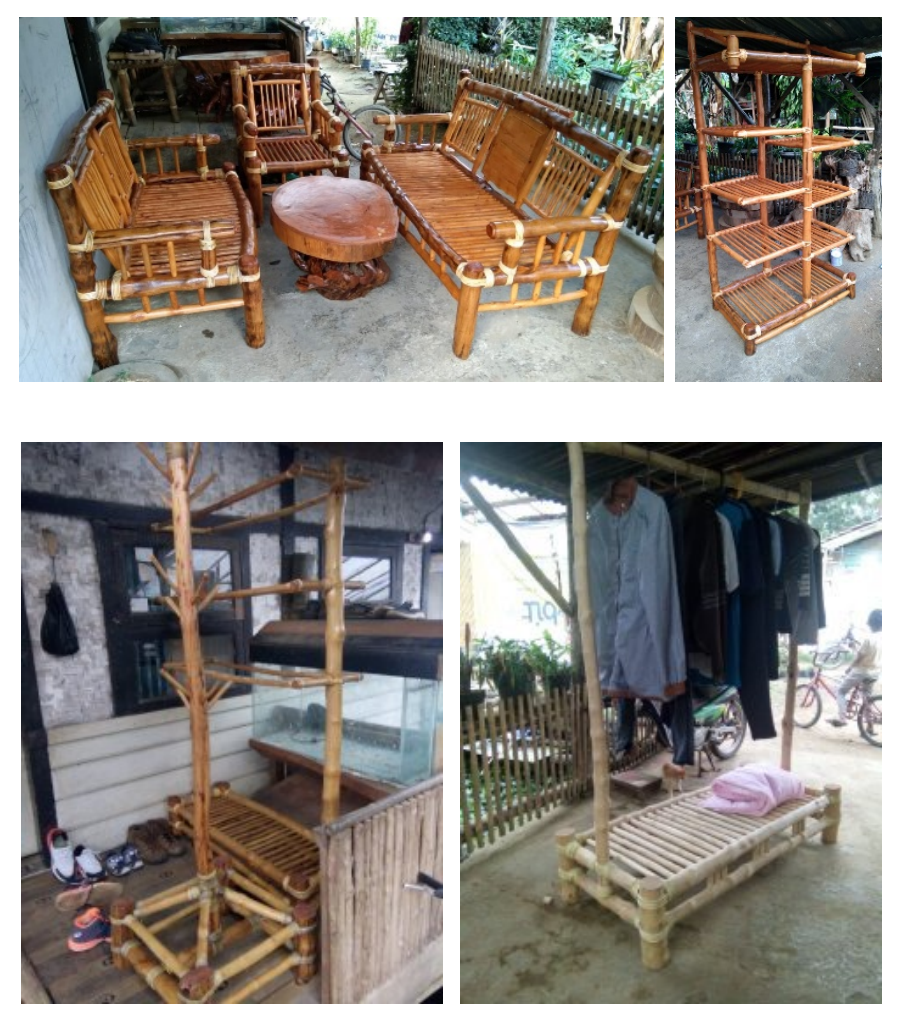

Gambar 9. Meja kursi, rak sepatu, gantungan topi, dan gantungan baju (Sumber: Dokumen Aep, tt)

Dilihat dari aspek kebudayaan, secara garis besar terdapat perkembangan wujud budaya pada ide dan tingkah laku sehingga tercipta mebel yang lebih beragam bentuk dan fungsi. Mebel-mebel dari limbah kina dibuat melalui tiga tahapan yaitu penyiapan bahan, pembentukan, dan penyelesaian. Tahap penyiapan bahan meliputi pemotongan batang kina dengan menggunakan gergaji. Batang kina selanjutnya direndam sekurangkurangnya satu jam agar mudah dibentuk dan dihaluskan. Pembentukan batang kina dengan menggunakan alat sugu serut. Setelah terbentuk kemudian dihaluskan dengan cara dihampelas. Bagian-bagian yang sudah terbentuk kemudian distel atau dipasang bagian per bagian untuk menjadi sebuah mebel. Penyetelan dengan menggunakan alat bor listrik, tatah, paku, dan gergaji. Bagian-bagian yang sudah terpasang kemudian dihaluskan lagi agar bagian sambungan lebih halus. Tahap penyelesaian berupa pelapisan dengan pelitur agar batang kina tidak mudah retak. Satu set mebel biasanya selesai dikerjakan dalam kisaran dua minggu. Hampir setiap bulan selalu ada pesanan mebel. Harga untuk satu set mebel terdiri atas meja, bangku untuk tiga dan dua orang, dan kursi harganya berkisar Rp 2.500.000,-. Bangku untuk duduk tiga orang seharga Rp 800.000,, pigura antara Rp 150.000,- sampai Rp 300.000,- rak sepatu Rp 800.000,- dan gantungan baju Rp 750.000,-.

Sampai sekarang, konsumen mebel kina masih terbatas pada mereka yang datang berwisata ke Agro Wisata Bukit Unggul yang di antaranya berasal dari Kabupaten Bandung, Kabupaten Garut, dan Kota Bandung. Selain itu konsumen berasal dari anggota batalion Zeni Tempur dan Secapa TNI AD yang sedang melakukan latihan di kawasan ini. Konsumen kerajinan mebel kayu kina merupakan faktor eksternal perubahan yang 
memberi pengaruh terhadap selera dan rasa keindahan sehingga model mebel mengikuti perkembangan zaman.

\section{SIMPULAN}

Umumnya orang mengenal kina hanya sebagai bahan obat dengan memanfaatkan kulit batangnya. Pemanfaatan pohon kina yang sebelumnya terbatas hanya satu bagian, tidak sebanding dengan investasi yang tinggi. Namun demikian, ada bagian dari pohon kina yang dapat dimanfaatkan, yaitu batang setelah diambil kulitnya. Pemanfaatan kina menjadi luas, tidak sebatas obat, tetapi juga material bangunan dan kerajinan. Pemanfaatan dan pengembangan limbah kina menjadikan kerajinan kayu kina bisa ditemui di rumah. Perluasan kebermanfaatan pohon kina memungkinkan menghidupkan Kembali perkebunan kina. Hidupnya kembali perkebunan kina akan mengembalikan kejayaan kina di masa lalu, dapat memperluas lapangan pekerjaan, dan membantu meningkatkan perekonomian masyarakat.

\section{DAFTAR PUSTAKA}

Fauzi, Rizal Achmad. 2017. "Strategi Pengembangan Daya Tarik Wisata Kebun Kina Bukit Tunggul di Kabupaten Bandung." Manejemen Resort dan Leisure 14 (2): 69-81.

Kartodirdjo, Sartono. 1975. Sejarah Nasional Indonesia. Jakarta: Departemen Pendidikan dan Kebudayaan.

Kartodirdjo, Sartono, dan Djoko Surjo. 1991. Sejarah Perkebunan di Indonesia: Kajian Sosial Ekonomi. Yogyakarta: Aditya Media.

Koentjaraningrat. 1990. Kebudayaan Mentalitas dan Pembangunan.

Nuralia, Lia, dan Iim Imadudin. 2021. "Nilai Budaya Pada Lanskap Industri Perkebunan Kina Cinyiruan Bandung Pada Masa Kolonial.” Patanjala 13 (2): 175-92. https://doi.org/10.30959/patanjala.v13i2.848.

Nuralia, Lia, Nanang Saptono, Bambang Setia Budi, Pahlawan Putra Satria Negara, Sukirja, Widarwanta, Dayat Hidayat, Dede Saripudin, Azhar Rachman, dan Wulandari Retnaningtyas. 2018. "Bangunan dan Produksi Perkebunan Panglejardan Bukit Unggul Sukawana Kabupaten Bandung Barat, Provinsi Jawa Barat." Bandung.

Officieele Vereeniging voor Toeristenverkeer in Nederlandsch-Indie. 1939. Toeristenkaart van Bandoeng en Omstreken. Batavia: Topographical Service.

Proyek Penerbitan Buku Sejarah Jawa Barat. 1980. Sejarah Jawa Barat. Bandung: Pemerintah Daerah Provinsi Jawa Barat.

Rosyadi. 2011. "Komunitas Adat Kampung Mahmud di Tengah Arus Perubahan." Patanjala 3 (2): 331-47.

Rukmana, Asep Nana, Aviasti, Reni Amaranti, dan Muhammad Akbar Shakira. 2020. "Penetapan Potensi Unggulan Kecamatan di Kabupaten Bandung." Journal of Research and Technology 6 (1): 23-32. 
JURNAL PANALUNGTIK — Vol. 4, No. 2, Desember 2021: 61 - 74

Saebani, Beni Ahmad. 2012. Pengantar Antropologi. Bandung: Pustaka Setia.

Sumaryono, Imron Riyadi, Tri Panji, Salwalubnan D., dan Diah Ratnadewi. 2009. "Produksi Kuinolin Secara Cepat dari Kultur Jaringan Tanaman Kina."

Wanti, Listiana Widya, Yusman Syaukat, dan Bambang Juanda. 2014. "Analisis Nilai Ekonomi Wisata Kebun Kina Bukit Unggul Kabupaten Bandung." Jurnal Ekonomi Pertanian, Sumber Daya dan Lingkungan 1 (2): 44-55. https://doi.org/10.29244/jaree.v1i2.11801.

Widjaya, Anto Sumiarto. 2009. Ujungberung Serambi Timur Bandung. Bandung: Genta Bunda. 